\title{
APLIKASI METODE PERAMALAN HOLTH WINTERS EXPONENTIAL SMOOTHING PADA DATA JUMLAH KEJADIAN HIPERTENSI
}

\author{
Wisoedhanie Widi ${ }^{1}$, Maria Prieska PPA ${ }^{2}$ \\ 1. Prodi DIII Keperawatan, STIKes Panti Waluya Malang (Email: wisoedhanie.widi@gmail.com) \\ 2. Prodi DIII Keperawatan, STIKes Panti Waluya Malang (Email: mariaprieska.mp@gmail.com)
}

\begin{abstract}
ABSTRAK
Pendahuluan Dalam usaha melihat dan mengkaji situasi dan kondisi yang terjadi di masa yang akan datang harus dilakukan peramalan (forecasting). Hipertensi menempati urutan sepuluh besar penyakit di Puskesmas Bareng dan hampir setiap bulan terjadi kasus baru hipertensi, sehingga kejadian hipertensi menjadi trend dan perlu dilakukan peramalan.

Tujuan Tujuan dari penelitian ini adalah melakukan peramalan pada data jumlah kejadian hipertensi di Puskesmas Bareng Kota Malang dengan menggunakan metode Holth Winters Exponential Smoothing.

Metode Jenis penelitian yang digunakan adalah non reactive research yang merupakan jenis penelitian untuk data sekunder. Unit sampel dalam penelitian ini adalah pasien yang datang berobat dan tercatat sebagai pasien hipertensi di Puskesmas Bareng Kota Malang.pada tahun 2013 hingga 2016. Data penelitian diolah menggunakan software Minitab.

Hasil Hasil dari penelitian ini menunjukkan kejadian hipertensi untuk tahun 2018 mengalami penurunan, dengan angka kejadian terendah terjadi pada bulan Desember yaitu sebanyak sebanyak 58 kejadian. Adanya tren penurunan kejadian hipertensi dapat didukung oleh faktor internal, yaitu jenis kelamin; dan faktor eksternal, yaitu lingkungan.
\end{abstract}

Kata Kunci : Hipertensi, Holth Winters Exponential Smoothing

\begin{abstract}
Introdaction In an effort to see and assess the situation and conditions that occur in the future should be DONE A forecasting. Hypertension diseases always ranks on the top ten in Puskesmas Bareng and almost every month occured new cases of hypertension, so the incidence of hypertension becomes a trend and need to be forecasted.

Aim The purpose of this study is to forecast data on the number of incidence of hypertension in Puskesmas Bareng with Holth Winters Exponential Smoothing method.

Metold The type of research used is non reactive research which is kind of research for secondary data. The sample unit in this study were patients who came for treatment and recorded as hypertensive patients at the Health Center Bareng Malang in 2013 to 2016. The research data is processed using Minitab software. The results of this study showed the incidence of hypertension for the year 2018 decreased, with the lowest incidence occurred in December that as many as 58. The existence of a decrease in the incidence of hypertension can be supported by internal factors, gender; and external factors, the environment.

Results Outcome in this research is research article, Graph of Trend of Morbidity of Hypertension Disease Rate at Puskesmas Bareng and study as teaching material. Through the results of this study, it is recommended the Puskesmas to develop planning and work control for eradication and transmission of hypertension.
\end{abstract}

Keywords: Forecasting, Hypertension, Exponential Smoothing 


\section{PENDAHULUAN}

Peramalan (forecasting) adalah kegiatan mengestimasi apa yang akan terjadi pada masa yang akan datang. Peramalan diperlukan karena adanya perbedaan kesenjangan waktu (time lag) antara kesadaran akan dibutuhkannya suatu kebijakan baru dengan waktu pelaksanaan kebijakan tersebut (Makridakis, 1998 dalam Fani dkk, 2017). Peramalan menjadi sangat penting bagi perencanaan yang efektif dan efesien dan menjadi dasar bagi perencanaan jangka panjang maupun jangka panjang bagi pemangku kebijakan (Makridakis, 1998 dalam Fani dkk, 2017).

Pada dasarnya peramalan ada dua macam yaitu peramalan kualitatif dan peramalan kuantitatif. Salah satu metode peramalan kuantitaif yang dapat digunakan adalah peramalan yang didasarkan pada deret waktu (time series). Time series adalah suatu rangkaian atau seri dari nilai-nilai suatu variabel atau hasil observasi, dalam hal ini adalah segala sesuatu yang dicatat dalam jangka waktu yang berurutan (Atmaja, 2009). Metode time series didasarkan atas penggunaan analisa pola hubungan antara variabel yang akan diperkirakan dengan variabel waktu yang merupakan deret waktu. Secara garis besar metode time series dikelompokkan menjadi metode averaging, metode smoothing, dan metode regressi (Box-Jenkins, 2008 dalam Safitri, 2017).

Pada awalnya analisis deret waktu berkembang dalam bidang ekonomi, khususnya ekonometrika (Green, 1993 dalam Juanda \& Junaidi, 2010). Penelitian dalam bidang kesehatan dan kedokteran telah banyak menggunakan deret waktu untuk mengevaluasi angka morbiditas dan mortalitas baik dalam menganalisis pola penyakit infeksi maupun dalam menganalisis pola penyakit non infeksi (Nawangwulan, 2016).

Analisis time series ini dapat diterapkan pada penyakit hipertensi. Hipertensi sebagai the silent killer merupakan faktor utama masalah morbiditas dan mortalitas (Bonita, 2001; Balitbangkes, Depkes RI, 2006). Hipertensi yang tidak terkontrol akan meningkatkan resiko mengalami terkena serangan jantung, arteriosclerosis, kerusakan ginjal, masalah pembuluh darah, dan stroke (Mamahit, 2017).

Menurut WHO dan The International Society of Hypertention (ISH), saat ini terdapat 600 juta penderita hipertensi di seluruh dunia, dan 3 juta diantaranya meninggal setiap tahunnya. Tujuh dari setiap 10 penderita tersebut tidak mendapatkan pengobatan yang tepat (WHO-ISH, 2003; JNC-7, 2003). Di Indonesia masalah hipertensi cenderung meningkat (Riskesdas, 2013). Hasil Survei Kesehatan Rumah Tangga (SKRT) tahun 2001 menunjukkan bahwa 8,3\% 12 Copyright @ 2019, JKM, p-ISSN 2088-6098, e-ISSN 2550-0538 
penduduk menderita hipertensi dan meningkat menjadi 27,5\% pada tahun 2004 (Depkes RI, 2004). Hasil SKRT 1995, 2001, 2004, menunjukkan penyakit kardiovaskuler merupakan penyebab kematian nomer satu di Indonesia dan sekitar 20-35\% dari kematian tersebut disebabkan oleh hipertensi. Riskesdas 2013 menunjukkan prevalensi hipertensi di Indonesia sebesar $26,5 \%$.

Puskesmas Bareng merupakan salah satu penyelenggara upaya pelayanan kesehatan masyarakat tingkat pertama dan upaya kesehatan perorangan tingkat pertama. Upaya kesehatan masyarakat tingkat pertama yang dilaksanakan meliputi upaya kesehatan masyarakat esensial dan upaya kesehatan masyarakat pengembangan. Upaya kesehatan masyarakat esensial meliputi pelayanan promosi kesehatan, kesehatan lingkungan, kesehatan ibu, anak dan keluarga berencana, gizi serta pencegahan dan pengendalian penyakit.

Fenomena yang diperoleh pada saat peneliti melakukan survey asuhan keperawatan pada keluarga resiko tinggi di wilayah kerja Puskesmas Bareng, diperoleh satu keluarga dengan masalah kesehatan hipertensi. Keterangan yang diperoleh dari pembimbing puskesmas mengatakan bahwa kasus hipertensi di Puskesmas Bareng tergolong banyak. Hampir setiap bulan terjadi kasus baru hipertensi. Hasil studi pendahuluan yang dilakukan di Puskesmas Bareng, menunjukkan bahwa pada tahun 2016 hipertensi menempati urutan pertama pada 10 besar penyakit di Puskesmas Bareng dengan jumlah penderita baru dan lama mencapai 2539. Berdasarkan data tersebut peneliti ingin melakukan peramalan (forecasting) menggunakan analisa deret waktu (time series) Double Exponential Smoothing pada angka kejadian hipertensi berdasarkan data jumlah kejadian hipertensi pada tahun sebelumnya di Puskesmas Bareng, dengan terlebih dahulu mengidentifikasi pola penyakit hipertensi yang ada di Puskesmas Bareng untuk kemudian dilakukan peramalan jumlah kejadian hipertensi di Puskesmas Bareng.

\section{METODE}

Jenis penelitian yang digunakan adalah penelitian non reaktif (non reactive research) yang merupakan jenis penelitian untuk data sekunder. Penelitian non rekatif disebut juga penelitian unobstrusive dimana sejumlah individu yang diteliti tidak sadar bahwa mereka merupakan bagian dari penelitian, tetapi meninggalkan bukti dari perilaku sosial secara ilmiah. Dengan kata lain, dalam penelitian unobstrusive tidak terdapat reaksi dari subjek penelitian. Penelitian bersifat tidak mengganggu subjek penelitian dan subjek penelitian juga tidak merasa terganggu (Kuntoro, 2011). 
Berdasarkan waktu penelitian, penelitian ini merupakan penelitian cross sectional. Berdasarkan tujuan dan sifat masalah, penelitian ini merupakan penelitian analitik dengan pendekatan observasional. Penelitian ini dilakukan di Puskesmas Bareng Kota Malang dengan mengambil jumlah kejadian hipertensi pada bulan Nopember 2017 hingga Pebruari 2018. Populasi dalam penelitian ini adalah seluruh pasien yang datang berobat dan tercatat sebagai pasien hipertensi di Puskesmas Bareng Kota Malang. Unit sampel dalam penelitian ini adalah pasien yang datang berobat dan tercatat sebagai pasien hipertensi di Puskesmas Bareng Kota Malang.pada tahun 2013 hingga 2016. Variabel yang digunakan dalam penelitian ini, yaitu variabel waktu dan variabel jumlah kejadian hipertensi. Variabel waktu dapat dikatakan sebagai variabel bebas yang akan mempengaruhi angka kejadian hipertensi di masa yang akan datang.

Data yang digunakan dalam penelitian ini bersifat data sekunder, dengan demikian peneliti menggunakan data yang telah tercatat dan didokumentasikan secara resmi sebagai data sistem informasi kesehatan tentang jumlah kejadian penyakit hipertensi di Puskesmas Bareng Kota Malang. Data yang digunakan oleh peneliti adalah data jumlah kejadian hipertensi pada tahun 2013 hingga 2016. Peneliti merekap data pasien yang datang berobat dan tercatat sebagai pasien hipertensi mulai tahun 2013 hingga tahun 2016. Data penelitian diolah dengan menggunakan metode peramalan. Metode peramalan yang digunakan yaitu Holth Winters Exponential Smoothing. Metode peramalan Holth Winters Exponential Smoothing diolah menggunakan software Minitab.

\section{HASIL}

\section{Gambaran Penderita Hipertensi di Puskesmas Bareng}

Data penderita hipertensi yang digunakan dalam penelitian ini adalah data kejadian hipertensi di Puskesmas Bareng Kota Malang pada 4 (empat) tahun sebelumnya, yaitu data kejadian hipertensi pada tahun 2013, 2014, 2015 dan 2016. dapat dilihat pada tabel 1. Tabel 1 menunjukkan bahwa kejadian hipertensi di Puskesmas Bareng Kota Malang menunjukkan fluktuasi yang berubah-ubah di setiap bulan dari tahun 2013, 2014, 2015 dan 2016.

\section{Peramalan Time Series Menggunakan Exponential Smoothing}

1) Identifikasi Plot Data atau Scatter Diagram

Plot pada data asli kejadian hipertensi di Puskesmas Bareng Kota Malang pada bulan Januari 2013 sampai dengan bulan Desember 2016, dan diperoleh hasil yang dapat dilihat pada gambar1. Gambar 1 menunjukkan dalam tahun yang sama, pada saat tertentu dalam 
satu tahun tersebut terjadi peningkatan dan penurunan berulang pada saat yang lain pada waktu yang sama, hal tersebut berulang pada tahun berikutnya. Terlihat peningkatan kejadian hipertensi setiap tahunnya pada bulan Januari dan mengalami fluktuasi yang sama pada bulan Juli hingga tahun 2015, hal ini menunjukkan bahwa pola data bersifat seasonal atau musiman. Pada bulan Januari tahun 2016 terjadi penurunan kejadian hipertensi, namun data tetap berfluktuasi dengan angka kejadian yang lebih rendah dari tahun-tahun sebelumnya.

Gambaran plot data kejadian hipertensi di Puskesmas Bareng pada Tahun 2013 hingga tahun 2016 menunjukkan bahwa data mengandung unsur seasonal atau musiman sehingga dapat ditentukan metode peramalan yang dapat digunakan adalah metode Winters Exponential Smoothing bukan metode Double Exponential Smoothing. Nilai uji root dengan statistic Augmented Dickey Fuller menunjukkan nilai probabilitas sebesar 0,6013 lebih besar daripada nilai $\alpha 5 \%$ sehingga dapat dikatakan data tidak stasioner . Nilai statistic $-1,343619$ kurang dari nilai kritis Mackinnon dengan $\alpha$ 5\% adalah -2,926622 artinya menunjukkan bahwa data tidak stasioner. Data yang tidak stasioner mengindikasikan bahwa data tidak sesuai apabila dilakukan peramalan dengan menggunakan pendekatan Single Exponential Smoothing. Adanya pola musiman dari data kejadian hipertensi merujuk pada pendekatan metode peramalan Holt Winters Exponential Smoothing.

\section{2) Menentukan Panjang Musiman}

Data kejadian hipertensi di Puskesmas Bareng memiliki panjang musiman atau periode musiman adalah 12 karena data disusun berdasarkan data setiap bulan, dengan periode waktu selama 4 tahun, yaitu mulai tahun 2013, 2014, 2015 dan 2016.

\section{3) Menentukan Nilai Awal Pemulusan}

Nilai awal taksiran untuk model multiplikatif diperoleh nilai inisialisasi pemulusan $\left(S_{0}\right)$ adalah 421,5833 yang merupakan rata-rata dari beberapa nilai musim yang sama. Inisialisasi faktor trend $\left(b_{0}\right)$ adalah $-0,82639$ dan inisialisasi faktor musiman $\left(l_{k}\right)$ untuk penghalusan musiman yaitu $l_{1}=1,190749 ; l_{2}=1,041313 ; l_{3}=1,010476 ; l_{4}=$ 0,$863412 ; l_{5}=0,982012 ; l_{6}=1,055545 ; l_{7}=1,055545 ; l_{8}=0,96778 ; l_{9}=$ 1,$167029 ; l_{10}=0,749555 ; l_{11}=1,00336 ; l_{12}=0,91322$ 


\section{4) Pendugaan Parameter $\alpha, \beta, \gamma$}

Parameter terbaik untuk nilai $\alpha, \beta, \gamma$ pada peramalan dilakukan dengan metode trial dan error. Nilai konstanta pemulusan didasarkan pada MAPE, MAD dan MSE yang diperoleh melalui aplikasi minitab ditunjukkan pada tabel 3.

\section{5) Menentukan Parameter $\alpha, \beta, \gamma$}

Perhitungan semua $\alpha, \beta, \gamma$ yang telah dilakukan menghasilkan 27 kombinasi model. Beberapa model yang terbentuk tersebut dipilih model yang terbaik, yang merupakan kombinasi $\alpha=0,3 ; \gamma=0,2$ dan $\beta=0,1$ dengan nilai Mean Average Percentage Error (MAPE) sebesar 12,04, nilai Mean Average Deviation (MAD) sebesar 35,00 dan nilai Mean Square Error (MSE) sebesar 3806,39.

Nilai MAPE sebesar 12,04 menunjukkan bahwa rata-rata absolut perbedaan nilai asli dan nilai peramalan pada data bulan pertama tahun 2013 hingga bulan terakhir tahun 2016 adalah sebesar $12,04 \%$. Nilai MAD menunjukkan besarnya rata-rata absolut penyimpangan dari nilai asli sebesar 35, dan MSE menunjukkan kuadrat dari rata-rata kesalahan yaitu sebesar 3806,3 .

\section{6) Menentukan Persamaan Model}

Model dengan $\alpha=0,3 ; \gamma=0,2$ dan $\beta=0,1$ adalah model terbaik. Sehingga persamaan model pemulusan eksponential data asli adalah $S_{t}=0,3 \frac{X_{t}}{l_{t-l}}+0,7\left(S_{t-1}+b_{t-1}\right)$, pemulusan pola trend yaitu $b t=0,1\left(S_{t}-S_{t-1}\right)+0,9 b_{t-1}$ dan pemulusan pola musiman yaitu $l_{t}=$ $0,2\left(X_{t}-S_{t}\right)+0,8 l_{m t-12}$ dan peramalan m untuk periode ke depan yaitu $F_{t+m}=S_{t}+$ $b_{t} m+l_{m t-L+m}$

\section{7) Menentukan Nilai Peramalan Kejadian Hipertensi pada Tahun 2018}

Gambar 2 menunjukkan hasil peramalan Winters Exponential Smoothing yang menghasilkan plot time series tetapan awal dimana menampilkan nilai-nilai series yang sesuai (fitted) satu periode di depan peramalan bersamaan dengan 12 peramalan. Peramalan tersebut menggunakan parameter pemulusan yang bernilai $\alpha=0,3, \gamma=0,2, \beta=0,1$. Secara deskriptif menunjukkan bahwa kejadian hipertensi menunjukkan penurunan mulai pada bulan ke 49 hingga bulan ke 70 .

Tabel 3 menunjukkan bahwa hasil peramalan kejadian hipertensi untuk tahun 2018 mengalami trend penurunan, dengan kejadian tertinggi terjadi pada bulan Januari yaitu sebanyak 135,068 136 kejadian dan kejadian terendah terjadi pada bulan Desember yaitu sebanyak 57,228 58 kejadian 


\section{8) Akurasi Nilai Peramalan}

Akurasi penilaian diperoleh dari nilai MAPE, MSE dan MAD yang menunjukkan nilai terkecil, yaitu nilai Mean Average Percentage Error (MAPE) sebesar 12,04, nilai Mean Average Deviation (MAD) sebesar 35,00 dan nilai Mean Square Error (MSE) sebesar 3806,39 .

\section{PEMBAHASAN}

Tabel 1 menggambarkan jumlah kejadian hipertensi di puskesmas Bareng Kota Malang mulai tahun 2013 hingga 2016 yang disusun menggunakan jumlah kejadian berdasarkan urutan waktu (bulan), sehingga data kejadian hipertensi tergolong pada data time series. Hal tersebut sesuai dengan yang disampaikan oleh Sriandari (2015) bahwa data time series merupakan data yang dikumpulkan, dicatat atau diobservasi sepanjang waktu secara berurutan dengan beberapa periode waktu yang dapat berupa periode tahun, kuartal, bulan, minggu atau juga dapat berdasarkan kasus hari atau jam. Data time series dapat dianalis untuk menentukan pola variasi data di masa lalu yang selanjutnya dapat digunakan untuk memprediksi nilai di waktu yang akan datang (forecast). Pernyataan tersebut didukung oleh Wijayanti (2012) juga mengemukakan bahwa data yang digunakan dalam penelitiannya adalah data time series yaitu data tentang Indeks Harga Perdagangan Besar Indonesia yang berurutan dari periode bulan Januari tahun 2006 hingga bulan April tahun 2012.

Data kejadian hipertensi di puskesmas Bareng Kota Malang mulai tahun 2013 hingga 2016 mengalami fluktuasi setiap bulannya yang ditunjukkan oleh hasil plot series yang menampilkan adanya pola musiman dan tidak stasioner. Hal tersebut didukung oleh pernyataan Fani (2017) bahwa pola musiman terjadi bilamana suatu deret dipengaruhi oleh faktor musiman, misalnya kuartal tahun, bulanan atau hari-hari pada minggu tertentu. Data kejadian hipertensi di puskesmas Bareng Kota Malang pada tahun 2013 hingga 2016 memiliki 48 titik pengamatan yang disusun berdasarkan laporan setiap bulan, dengan demikian dapat dikatakan bahwa data time series kejadian hipertensi di puskesmas Bareng Kota Malang memiliki panjang musiman sebanyak 12. Menurut Kalekar (2004) dalam Safitri (2017) Data musiman berarti kecenderungan menguangi pola tingkah gerak dalam periode musiman, biasanya satu tahun. Runtun waktu musiman mempunyai karakteristik yang ditunjukkan oleh adanya korelasi beruntun yang kuat pada jarak semusim yakni waktu yang berkaitan dengan banyak observasi per periode musiman. 
Penelitian time series memiliki beberapa pendekatan dalam menentukan metode yang akan digunakan. Exponential Smoothing merupakan metode yang menggunakan bobot yang berbeda pada setiap periode waktunya dan membentuk fungsi exponential. Peramalan dilakukan dengan menggunakan pendekatan exponential smoothing karena data pengamatan yang digunakan kurang dari 50 pengamatan. Hasil plot data menunjukkan pola data yang non stasioner, berfluktuasi setiap bulannya dan mengandung unsur seasonal (musiman) maka pendekatan yang digunakan adalah Triple Exponential Smoothing. Metode penghalusan Exponential Tripel dari Winters lebih dikenal dengan metode Holt-Winters. Metode Winters menggunakan sebuah komponen level, sebuah komponen tren dan sebuah komponen musiman pada tiap periode. Menggunakan tiga bobot atau parameter penghalusan untuk memperbaharui komponen pada tiap periode (Makridakis, 1999 dalam Raihan, 2016). Safitri (2017) juga menyampaikan metode Exponential Smoothing Holt Winters merupakan metode sederhana dan mudah dipraktikkan pada model peramalan dengan metode musiman.

Penentuan nilai awal pada peramalan winters dapat dilakukan dengan menggunakan data paling sedikit satu kelompok data musiman lengkap yaitu pada penelitian ini menggunakan data pada tahun 2013 dan selanjutnya dihitung dengan menggunakan rumus $\frac{1}{l}\left(X_{1}+X_{2}+X_{3} \ldots+\right.$ $X_{l}$ ). Menurut Sriandari (2015) menjelaskan bahwa proses penentuan nilai awal atau yang biasa disebut proses inisialisasi sangat diperlukan untuk menentukan nilai pemulusan keseluruhan yaitu $s_{t}=\propto\left(\frac{x_{t}}{l_{t-1}}\right)+(1-\propto)\left(S_{t-1}+b_{t-1}\right)$. Dantas (2017) juga menjelaskan bahwa proses memperoleh nilai inisialisasi merupakan bagian dari tahap ketiga yaitu forecasting untuk memperoleh nilai pemulusan.

Penentuan parameter $\alpha, \beta, \gamma$ menggunakan cara simulasi yaitu dengan memasukkan semua kemungkinan nilai konstanta untuk dapat dipilih nilai mana yang dapat meminimumkan nilai MAPE, MAD dan MSE. Kerugian yang diperoleh dari perhitungan dengan cara simulasi atau trial dan error adalah memakan waktu yang lama akan tetapi dapat menghasilkan nilai konstanta yang maksimal (Makridakis, 1999 dalam Safitri 2017). Sungkawa dan Megasari (2011) juga menyampaikan bahwa menemukan nilai taksiran awal untuk kemudian menentukan nilai pemulusan terkecil antara 0,1 hingga 0,3 merupakan salah satu cara untuk membantu menemukan nilai optimal.

Hasil simulasi menunjukkan bahwa kombinasi nilai $\alpha=0,3, \gamma=0,2, \beta=0,1$ dapat menghasilkan nilai MAPE, MAD dan MSE yang terkecil. Hasil tersebut sesuai dengan yang 
dikemukakan oleh (Makridakis,1999 dalam Safitri, 2017) bahwa metode alternative yang dapat mengurangi keraguan tentang nilai optimal adalah mencari taksiran awal yang lebih baik, lalu menetapkan nilai yang lebih kecil untuk ketiga parameter pemulusan yaitu sekitar 0,1 sampai dengan 0,3. Nilai 0,1 membuat ramalan bersifat terlalu hati-hati, sedangkan nilai 0,3 memberikan sistem yang lebih responsive. Tabel 2 menunjukkan model terbaik pada peramalan kejadian hipertensi di puskesmas Bareng Kota Malang diperoleh dari nilai $\propto=0,3 \beta=0,1$ dan $\gamma=0,2$ yang menghasilkan nilai $\mathrm{MAPE}=12,04, \mathrm{MAD}=35,00$ dan $\mathrm{MSE}=3806,39$ yang terkecil. Hasil tersebut didukung oleh penelitian Pratama, dkk (2016) tentang peramalan total pendapatan bea dan cukai dengan menggunakan double exponential smoothing dengan nilai akurasi peramalan terbaik yaitu MAPE sebesar 12,974\%, MAD sebesar 13.235,1957 dan MSE sebesar 330.096.599,2381 pada $\alpha$ 0,140. Penelitian Safitri, dkk (2017) tentang peramalan jumlah kedatangan wisatawan di Bandara Ngurah Rai Bali menyampaikan hal yang sama bahwa nilai model terbaik pada winters exponential smoothing diperoleh dari nilai $\propto=0,3 \beta=0,1$ dan $\gamma=0,1$ diperoleh nilai MAPE sebesar 8,86198\%, MSE sebesar 1436553590 .

Hasil peramalan kejadian hipertensi untuk tahun 2018 dengan menggunakan winters exponential smoothing menunjukkan adanya tren penurunan kejadian hipertensi selama tahun 2018. Adanya tren penurunan kejadian hipertensi dapat didukung oleh beberapa faktor, yaitu faktor internal dan eksternal. Berdasarkan hasil penelitian yang dijabarkan dalam Tabel 5.1 kejadian hipertensi lebih banyak terjadi pada perempuan daripada laki-laki. Menurut Sandberg dan Ji H (2012) dalam penelitiannya yang berjudul "Sex Difference in Primary Hypertension" menunjukkan prosentase angka kejadian hipertensi pada perempuan lebih tinggi daripada lakilaki pada responden berusia 50 - >69 tahun pada Non Hispanic White dan Mexican American, sedangkan pada Non Hispanic Black angka kejadian hipertensi pada perempuan lebih tinggi dari pada laki-laki untuk usia > 59 tahun. Pernyataan tentang hal tersebut didukung pula oleh penelitian yang menyatakan bahwa perempuan lebih cenderung mengalami hipertensi daripada laki-laki pada usia >60 tahun (Choi, Kim \& Kang, 2017). Shirani et all (2011) menyatakan bahwa tekanan darah pada wanita lebih tinggi daripada laki-laki pada usia 40-59 tahun dalam penelitiannya yang berjudul "Gender differences in the prevalence of hypertension in a representative sample of Iranian population: the Isfahan Healthy Heart Program”. Tingginya angka kejadian Hipertensi pada perempuan lebih sering terjadi pada perempuan yang telah menopause. Hal ini disebabkan oleh pengaruh hormon estrogen dimana berfungsi dalam regulasi tekanan darah. Wanita yang belum mengalami menopause dilindungi oleh hormon estrogen yang berperan dalam meningkatkan kadar High Density Lipoprotein (HDL). Kadar 
kolesterol HDL yang tinggi merupakan faktor pelindung dalam mencegah terjadinya proses arterosklerosis. Efek perlindungan estrogen dianggap sebagai penjelasan adanya imunitas wanita pada usia premenopause. Wanita premenopause mulai kehilangan sedikit demi sedikit hormon estrogen yang selama ini melindungi pembuluh darah dari kerusakan. Proses ini terus berlanjut dimana hormon estrogen tersebut berubah kuantitasnya sesuai dengan umur wanita secara alami, yang umumnya mulai terjadi pada wanita umur 45 - 55 tahun sebelum lanjut usia (Anggraini, Waren et. al, 2008). Kadar estrogen pada wanita dewasa sebanyak 20-300 pg/ ml, wanita menstruasi sebesar $30-800 \mathrm{pg} / \mathrm{ml}$, dan wanita post menopausal sebesar $<20 \mathrm{pg} / \mathrm{ml}$ (Stanczyk, Clarke, 2013).

Selain faktor internal yang telah dijelaskan pada paragraf sebelumnya, faktor eksternal mengambil bagian dalam penururnan angka kejadian Hipertensi pada responden. Faktor eksternal tersebut berupa faktor lingkungan, khususnya pelayanan kesehatan masyarakat. Berdasarkan data yang telah didapatkan, pelayanan kesehatan pada masyarakat Bareng (Puskesmas Bareng) telah melakukan berbagai upaya dalam tindakan preventif, promotif dan kolaboratif dalam penanganan masalah Hipertensi. Tindakan-tindakan tersebut berupa adanya kegiatan Prolanis dan Posyandu Lansia yang diperuntukkan bagi lansia yang diadakan secara regular dimana dalam kegiatan tersebut termasuk kegiatan penyuluhan tentang Hipertensi dan Senam Hipertensi bagi penderita Hipertensi (Puskesmas Bareng, 2018). Adanya program kesehatan dengan pemanfaatan jaminan kesehatan menurunkan resiko kegagalan kontrol tekanan darah (Sari, Listya, 2016). Adanya tindakan pencegahan untuk penanganan Hipertensi ini dapat mempengaruhi pengetahuan dan perilaku masyarakat khususnya gaya hidup sehat pada pasien Hipertensi (Maulana, 2009). Berdasarkan hasil penelitian, perempuan memiliki tingkat kesadaran (awareness) yang lebih tinggi dari laki-laki sehingga mempengaruhi perilaku kesehatan yang lebih baik (Egan \& Axon, 2012).

Faktor internal yang telah dijelaskan pada paragraf sebelumnya, faktor eksternal mengambil bagian dalam penururnan angka kejadian Hipertensi pada responden. Faktor eksternal tersebut berupa faktor lingkungan, khususnya pelayanan kesehatan masyarakat. Berdasarkan data yang telah didapatkan, pelayanan kesehatan pada masyarakat Bareng (Puskesmas Bareng) telah melakukan berbagai upaya dalam tindakan preventif, promotif dan kolaboratif dalam penanganan masalah Hipertensi. Tindakan-tindakan tersebut berupa adanya kegiatan Prolanis dan Posyandu Lansia yang diperuntukkan bagi lansia yang diadakan secara regular dimana dalam kegiatan tersebut termasuk kegiatan penyuluhan tentang Hipertensi dan Senam Hipertensi bagi penderita Hipertensi (Puskesmas Bareng, 2018). Adanya tindakan 20 Copyright @ 2019, JKM, p-ISSN 2088-6098, e-ISSN 2550-0538 
pencegahan untuk penanganan Hipertensi ini dapat mempengaruhi pengetahuan dan perilaku masyarakat khususnya gaya hidup sehat pada pasien Hipertensi (Maulana, 2009). Berdasarkan hasil penelitian, perempuan memiliki tingkat kesadaran (awareness) yang lebih tinggi dari pada laki-laki sehingga mempengaruhi perilaku kesehatan yang lebih baik (Egan \& Axon, 2012).

\section{KESIMPULAN}

Berdasarkan penelitian yang telah dilakukan didapatkan hasil sebagai berikut:

1. Metode exponential yang sesuai digunakan pada peramalan data kejadian hipertensi di Puskesmas Bareng Kota Malang adalah Holt Winters Exponential Smoothing

2. Akurasi penilaian diperoleh dari nilai MAPE, MSE dan MAD yang menunjukkan nilai terkecil, yaitu nilai Mean Average Percentage Error (MAPE) sebesar 12,04, nilai Mean Average Deviation (MAD) sebesar 35,00 dan nilai Mean Square Error (MSE) sebesar $3806,39$.

3. Hasil peramalan menunjukkan bahwa kejadian hipertensi untuk tahun 2018 mengalami penurunan, dengan angka kejadian terendah terjadi pada bulan Desember yaitu sebanyak sebanyak 57,228 58 kejadian.

Tabel 1: Kejadian Hipertensi di Puskesmas Bareng Kota Malang

\begin{tabular}{|c|l|c|c|c|c|}
\hline \multirow{2}{*}{ No } & \multirow{2}{*}{ Bulan } & \multicolumn{4}{|c|}{ Tahun } \\
\cline { 3 - 6 } & & $\mathbf{2 0 1 3}$ & $\mathbf{2 0 1 4}$ & $\mathbf{2 0 1 5}$ & $\mathbf{2 0 1 6}$ \\
\hline 1 & Januari & 502 & 502 & 502 & 225 \\
\hline 2 & Februari & 439 & 382 & 439 & 188 \\
\hline 3 & Maret & 426 & 426 & 426 & 276 \\
\hline 4 & April & 364 & 324 & 364 & 232 \\
\hline 5 & Mei & 414 & 414 & 414 & 224 \\
\hline 6 & Juni & 445 & 445 & 445 & 198 \\
\hline 7 & Juli & 445 & 439 & 439 & 173 \\
\hline 8 & Agustus & 408 & 408 & 463 & 224 \\
\hline 9 & September & 492 & 492 & 454 & 190 \\
\hline 10 & Oktober & 316 & 316 & 405 & 287 \\
\hline 11 & Nopember & 423 & 407 & 459 & 254 \\
\hline 12 & Desember & 385 & 385 & 432 & 185 \\
\hline
\end{tabular}

Sumber : Data laporan Puskesmas Bareng Kota Malang
Tabel 2. Konstanta Parameter $\alpha, \beta, \gamma$

\begin{tabular}{|c|c|c|c|c|c|}
\hline$(\boldsymbol{\alpha})$ & $(\gamma)$ & $(\boldsymbol{\beta})$ & MAPE & MAD & MSE \\
\hline 0,1 & 0,1 & 0,1 & 19,13 & 51,74 & 5582,89 \\
\hline 0,2 & 0,2 & 0,2 & 14,08 & 39,11 & 4399,91 \\
\hline 0,3 & 0,3 & 0,3 & 12,76 & 36,72 & 4240,37 \\
\hline 0,2 & 0,2 & 0,3 & 14,27 & 39,61 & 4552,56 \\
\hline 0,2 & 0,3 & 0,3 & 14,25 & 39,70 & 4147,17 \\
\hline 0,3 & 0,2 & 0,3 & 12,46 & 36,04 & 4098,48 \\
\hline 0,3 & 0,1 & 0,3 & 12,77 & 36,50 & 3926,36 \\
\hline 0,3 & 0,1 & 0,1 & 12,45 & 35,77 & 3662,71 \\
\hline 0,3 & 0,2 & 0,2 & 12,25 & 35,49 & 3949,93 \\
\hline 0,2 & 0,1 & 0,1 & 14,24 & 39,54 & 4157,14 \\
\hline 0,2 & 0,1 & 0,3 & 14,57 & 40,21 & 4440,39 \\
\hline 0,2 & 0,3 & 0,2 & 14,01 & 39,07 & 4568,79 \\
\hline 0,3 & 0,2 & 0,1 & 12,04 & 35,00 & 3806,39 \\
\hline 0,3 & 0,1 & 0,2 & 12,62 & 36,17 & 3793,42 \\
\hline
\end{tabular}


Tabel 3 Hasil Peramalan Kejadian Hipertensi

\begin{tabular}{|c|c|c|}
\hline No & $\begin{array}{c}\text { Waktu } \\
\text { (Tahun 2018) }\end{array}$ & $\begin{array}{c}\text { Kejadian } \\
\text { Hipertensi }\end{array}$ \\
\hline 1 & Januari & 135,068 \\
\hline 2 & Februari & 108,818 \\
\hline 3 & Maret & 113,910 \\
\hline 4 & April & 90,405 \\
\hline 5 & Mei & 97,956 \\
\hline 6 & Juni & 96,853 \\
\hline 7 & Juli & 89,304 \\
\hline 8 & Agustus & 86,231 \\
\hline 9 & September & 85,938 \\
\hline 10 & Oktober & 67,521 \\
\hline 11 & Nopember & 70,399 \\
\hline 12 & Desember & 57,228 \\
\hline
\end{tabular}

\section{DAFTAR PUSTAKA}

Atmaja, L.S. (2009). Statistika untuk Bisnis dan Ekonomi. Yogyakarta. Penerbit

Balitbangkes, Depkes RI. (2006). Operational Study an Immunity-Based Intervention Program On Common Major Non Communicable Disease in Depok Indonesia . Jakarta: Depkes RI.

Baradero et al (2008). Klien Gangguan Kardiovaskulear: Seri Asuhan Keperawatan. Jakarta: EGC

Basuki B, Setianto B. (2001). Age, Body, Posture, Daily Working Load Past Antihypertensive drug and Risk of Hypertension; a Rural Indonesia Study. Med J Indon.

Bonita R. (2001). Surveillance of Risk Factors for Non Communicable Disease; The WHO Stepwise Approach. Summary. Geneva; World Health Organization.

CDC. (1991-1999). State Specific Trend in Self Report $3^{\text {rd }}$ Blood Pressure Screening and High Blood Pressure. United States.

Dantas, T. M., F. L. C. Oliveira, et al. (2017). "Air transportation demand forecast through Bagging Holt Winters methods. Journal of Air Transport Management. 59: 116-123.

Darmojo B. (2000). Mengamati Penelitian Epidemiologi Hipertensi di Indonesia. Disampaikan pada seminar hipertensi PERKI.

Departemen Kesehatan. (2004). Survei Kesehatan Nasional. Laporan Departeman Kesehatan RI. Jakarta. 
Fani, E., F. A. Widjajati, et al. (2017). "Perbandingan Metode Winter Eksponensial Smoothing dan Metode Event Based untuk Menentukan Penjualan Produk Terbaik di Perusahaan X. JURNAL SAINS DAN SENI ITS. 6(1): 2337-3520.

Fretchling, D.c. (2001). Forecasting Tourism Demand: Methods and Strategies. Butterworth Heinemann, Oxford.

Ginsberg, Lionel (2008). Lecture Notes Neurologi. Jakarta: Erlangga

Hankey, GJ. (2002). Hipertensi: Long Term Dissability After First Ever Hipertensi And Related Prognostic Factors In The Perth Community Hipertensi Study, 1998-1990.

Joint National Committee on Prevention, Detection, Evaluation, and Treatment of High Blood Pressure (JNC). (2003). The Seventh Report of The JNC (JNC-7).

Kuntoro, H. (2011). Dasar Filosofis Metodologi Penelitian. Zifatama, Sidoarjo.

Makridakis, S, dkk. 1999. Metode dan Aplikasi Permalan, Jilid I edisi kedua. Jakarta: Binarupa Aksara.

Makridakis, S., Wheelwright, S. C., McGee V. E., (1992). Forecasting: Methods and Applications, $2^{\text {nd }}$ edition. John Wiley \& Sons Inc.

Mulyana. (2013). Penyakit Infeksius dan non infeksius http://yuzniemulyhana.blogspot.co.id/2013/10/penyakit-non-infeksi.html. 6 okt 2013. Diakses pada 3 Nopember 2017.

Nawangwulan, S. and D. Angesti (2016). "ANALISIS TIME SERIES METODE WINTER JUMLAH PENDERITA GASTROENTERITIS RAWAT INAP BERDASARKAN DATA REKAM MEDIS DI RSUD DR. SOETOMO SURABAYA. "Jurnal Manajemen Kesehatan STIKES Yayasan RS. Dr. Soetomo. 2(1): 17-32.

Raihan, M. S. Eff, et al. (2016). "FORCASTING MODEL EXSPONENSIAL SMOOTHING TIME SERIES RATA RATA MECHANICAL AVAILABILITY UNIT OFF HIGHWAY TRUCK CAT 777D CATERPILLAR. Jurnal POROS TEKNIK. 8(1): 154.

Safitri, T., N. Dwidayati, et al. ((2017) ). "PERBANDINGAN PERAMALAN MENGGUNAKAN METODE EXPONENTIAL SMOOTHING HOLT-WINTERS DAN ARIMA. UNNES Journal of Mathematics. 6 (1): 48-58.

Setiawan, Zamhir. (2006). Karakteristik Sosiodemografi sebagai Faktor Resiko Hipertensi Studi di Pulau Jawa tahun 2004 (Tesis). Program Studi Epidemiologi Program pasca Sarjana FKM-UI. Jakarta.

Tambayong, Jan (2000). Patofisiologi untuk Keperawatan. Jakarta: EGC

Wei, W.W.S. (2006). Time Series univariat and Multivariat Methods. $2^{\text {nd }}$ United States Of America: Pearson Education.

WHO (2008). Fact Sheet : The Top Ten causes Of Death. 28 Oktober 2017. www.who.int/mediacentre/factsheets/fs310_2008.pdf.

WHO/SEARO. (2005). Surveillance of Major Non Communicable Diseases in South East Asia region. Report of an Inter Country Consultation. Geneva; WHO-SEARO.

WHO-ISH. (2003). Hypertension Guideline Committee. Guidelines of The Management of Hypertension. J Hypertension

Wilterdink JL, Easton JD. (2001). Hipertensi Prevention In 2001. In: Bougosslavsky J. ed. Drug Theraphy For Hipertensi Prevention. London ; Taylor And Francis.

Wiyanti, D. and R. Pulungan (2012). "PERAMALAN DERET WAKTU MENGGUNAKAN MODEL FUNGSI BASIS RADIAL (RBF) DAN AUTO REGRESSIVE INTEGRATED MOVING AVERAGE (ARIMA). Jurnal MIPA. 35(2): 175-182.

Yastroki. (2009). Hipertensi Urutan Kedua Penyebab Kematian di Indonesia, www.yastroki.or.id 